\title{
'First catch your Weka': A tasting plate of recent New Zealand food writing
}

\begin{abstract}
This article surveys a range of recent food-related books and food writers from New Zealand, in order to identify and describe a variety of sub-genres, content and writing styles. Coming from a range of backgrounds, including culinary, literary, scholarly, journalistic and other areas, these contemporary New Zealand food writers range across a diverse variety of subject matter from all aspects of culinary matters to politics and environmental sustainability, history and human relationships as well as the many other aspects of social and cultural life that can be addressed under the broad umbrella of food as a topic. Although cookbooks are not included in this investigation, many of these books include recipes. It also identifies and describes a number of associations, institutions and publishers that support this sector of the writing and publishing industry in New Zealand.

Keywords: New Zealand food writing, Food writers, Helen Leach, Richard Till
\end{abstract}

\section{Introduction: Food for thought}

New Zealand has a developed literature in terms of fiction, with its well-known canonical works and writers, influential critics and leading publishers and booksellers the subject of historical and critical reflection and analysis (see, for example, Reid 1946, Griffith et al 1997, Sturm 1998, Robinson and Wattie 1998, Griffith et al 2000, Bullock 2007, Evans 2007). Creative writing courses are well established in New Zealand and the history of these courses, and their influence on New Zealand writers and writing, is also beginning to be written (Pittaway 2011). Although non-fiction life writing - such as autobiography, memoir and biography, and including journals and collections of correspondence - has also received critical and other attention (see, for instance, Sturm 1998), forms of non-fiction writing which can be read as less literary and more popular have received less consideration. The Preface to The Oxford Companion to New Zealand Literature (1998) includes recognition that 'New Zealand has produced far more film, radio and television writers, sports writers, journalists, historians and rock-music lyricists than are included' (Robinson and Wattie 1998) but there is, as yet, no history or companion to New Zealand non-fiction.

This review article recognizes that currently in New Zealand, in common with practice elsewhere in the Western world, writing about food is attracting not only an enthusiastic readership but also both new and established writers. Coming from a range of backgrounds, including culinary, literary, scholarly, journalistic and other areas, these contemporary New Zealand food writers range across a diverse range of subject matter from all aspects of culinary matters to politics and environmental sustainability, history and human 
relationships as well as the many other aspects of social and cultural life that can be addressed under the broad umbrella of food as a topic. Their writing styles are similarly diverse, including those with a very literary inflection, others with a scholarly modulation, to those which are much more accessible for readers. In common with many other non-fiction writers, these authors are flexible, varying their style and tone to match the publication in question, and whether they are writing for a newspaper, popular, general or specialist magazine, general non-fiction title or scholarly journal or book.

New Zealand food writers are supported by a range of associations, institutions and publishers. The New Zealand Food History Society, 'a community of academic and amateur food historians and aristologists [aristology being the art or science of cooking and dining], passionately interested in the culinary history of New Zealand' (NZFHS 2012) meets annually, and supports an expanding number of publishing ventures including a print journal, The Aristologist (first published in 2011), and a website. The New Zealand Guild of Food Writers has a wide remit as the professional body for not only food journalists, but also 'others involved in writing about, presenting, promoting, illustrating, and teaching about the specialist area of food and beverages'. The focus here is on how the work of these writers connects with readers, what the Guild calls "interface with the public" whether this is through writing for magazines, newspapers, radio and television or the writing that is involved in food publishing, teaching, consultancy, PR, catering and photography (NZGFW 2012). With a mission statement that it 'serves to educate, support and promote its members as professional food communicators', the Guild focuses on providing liaison opportunities with industry and a range of education activities - mounting a well-attended bi-annual conference and Culinary Quills awards program and hosting a series of educational seminars. The Guild also publishes Pen \& Palate, a bi-monthly publication containing articles on the food industry and media alongside information on the Guild and its members and further promotes the work of its members by maintaining a registry of what it calls 'professional practitioners' in the field (NZGFW 2012). A number of university presses include food-related titles in their lists, with Auckland University Press (AUP) and Otago University Press (OtUP) notable for the variety and quality of volumes they produce, which has been recognised by major awards. David Veart's First Catch Your Weka (AUP 2008) and Helen Leach's The Pavlova Story: A Slice of New Zealand's Culinary History (UOtP 2008) were, for instance, both finalists in the 2009 Montana New Zealand Book Awards. Commercial publishers produce erudite and well-illustrated food-related volumes with popular appeal, and bookshops around the country carry significant selections of locally produced volumes, including one in Auckland that specialises in cookbooks and other culinary material.

\section{New Zealand food writing: A degustation}

The article below introduces fourteen notable recent volumes of New Zealand food writing and chosen, in a simulation of a degustation menu, to indicate the variety of content and styles of writing currently in publication in that country. In doing so, it does not include any of the many wonderful cookbooks written and published in New Zealand, although these writers make an important contribution to the literary, as well as the culinary, landscape of Aotearoa. The history and current state of New Zealand cookbook publication is certainly worthy of detailed consideration, but will not be herein addressed. That said, almost all of the books below include recipes in some form, but relaying such information is not their main orientation. Nor does this survey include any of the published writing in serials or online, or books with a primarily technical, 
dietary or scientific purpose. Instead, it seeks to profile a range of quality books about food that are relevant and useful to those with an interest in writing about food and/or teaching food writing as a genre. It also seeks to profile (however briefly) a number of the writers who have made important contributions to this culinary literature since 2008. This year has no special significance in itself, other than it allows books from more than a single year to be included but keeps the books chosen restricted to a relatively short period of publication. The focus and tone of the discussion follows Denis McEldowney's call for a book history that 'goes beyond the content of books to the book itself as an object, to its history, to the interrelated details of its gestation and production, and to its influence on readers and the world' (McEldowney 2000: vii).

A significant number of these volumes take a historical approach, mapping changes in New Zealand cuisine and its traditions and institutions over time. One of the earliest, anthropologist and archaeologist David Veart's First Catch your Weka: A Story of New Zealand Cooking ([2008] 2009), from which I take the title of this article, is a 'story of New Zealand cooking as it is recorded in ... cookbooks and ... recipes' (2). With these sources as his basis, Veart uses a chronological structure to scaffold a series of informative thematic examinations of New Zealand society, technology and culture, and to frame a discussion that he describes as 'the gradual emergence of a set of food behaviours which are identifiably our own' (7). This engaging text is illustrated with gorgeous reproductions of archival photographs, advertisements and pages from old cookery books. Each chapter includes a series of recipes from the era, and the volume is supplemented with detailed notes, an extensive bibliography and indexes of recipes and content. David Burton's New Zealand Food and Cookery (2009) is a similarly comprehensive and well-written study of food and cookery from Maori foodways and the early days of white settlement (1769 onwards) to the restaurant cultures of the 1960s and 1970s and the contemporary 'fusion, retro \& beyond' (95). The second half of the volume comprises recipes from each of these periods, and while additional information introduces them, recipes are organised by dish type (soups, fish, puddings and desserts and so forth) instead of historical period. This volume also includes an extensive reference list and an excellent index.

Whereas Veart focuses on cookery in general, including home cooking, and Burton examines a wide range of foods and how they can be prepared, Perrin Rowland's beautifully-written Dining Out: A History of the Restaurant in New Zealand charts the rise (and sometimes fall) of restaurant culture in New Zealand. Rowland reveals some commonalities between New Zealand and Australian restaurant history, but also some strong differences, since the history of restaurant premises, employees, what was cooked and what was eaten is affected by local/national habits, culture, economic realities and legislation as well as international politics, trends and influences in both countries. This skillfully-structured narrative tells the fascinating stories of the people and meals behind the photographs and menus with which it is richly illustrated. Well-known writer and media figure Keith Stewart charts the sometimesdramatic history of the New Zealand wine industry with Chancers and Visionaries: A History of New Zealand Wine (2010). According to Stewart, the diverse but always-energetic group of passionate producers, merchants, restaurateurs, entrepreneurs and enthusiasts who people this chronology 'are bound together by their singular ideal of quality with integrity' (14). Like the three previous texts, this is an erudite, entertaining and superbly-produced book filled with gripping stories and revealing anecdotes, and although possessed of the full and very useful scholarly apparatus of notes, picture credits, extensive bibliography and index, is both a pleasure to hold and to look at. 
The now-iconic dessert, the pavlova, first introduced me to Helen Leach (Emeritus Professor of Anthropology at the University of Otago in Dunedin) and her meticulous and fascinating work on New Zealand culinary history. The Pavlova Story: A Slice of New Zealand's Culinary History (2008) examines the thorny question of whether the cream-filled meringue, said to be based on the ballerina Anna Pavlova, is a New Zealand or Australian creation. Her book is a model for how a single-dish survey can be written and presented: thorough research resulting in informative and authoritative data conveyed in a highlyengaging style and supported with numerous illustrations and carefully-tested classic pavlova recipes that work in today's kitchens. From Kai to Kiwi Kitchen: New Zealand Culinary Traditions and Cookbooks (Leach 2010) includes three informative lectures by Leach on the 'edible items, material culture and artefacts, customs and ideas' (15) that make up New Zealand culinary tradition. These correspond to three periods of New Zealand history: Maori cookery before Cook's arrival, colonial cookery and twentieth century cookery. The volume also contains five essays: F. Jane Teal's captivating survey of changes in kitchen technology, Janet Mitchell's interesting essay on the influence of ideas about nutrition on twentieth-century cookbooks, Duncan Galletly's absorbing comparative study of fish and seafood recipes in 380 cookbooks from 1887 and 1950, Raelene Inglis's thought-provoking essay on the work of the University of Otago's School of Home Science and Michael Symon's lively comparison of two much-loved New Zealand food writers, Maud Ruby Basham ('Aunt Daisy') and Lois Daish. The Twelve Cakes of Christmas: An Evolutionary History with Recipes (2011), produced by Leach with food writer Mary Browne and researcher Raelene Inglis, surveys this iconic celebration cake, expressing the findings from scholarly research in wonderfully-accessible writing, beautiful full-colour photography and carefully-tested recipes.

Another prominent strand of New Zealand food writing is indicated in Wendyl Nissen's A Home Companion: My Year of Living Like my Grandmother (2010). As self-acknowledged 'hard-bitten' magazine editor and journalist, Nissen charts her quest to 'get her hands covered in soil, rid her house of nasty chemicals, nurture her family and become a green goddess' (8). Others in a series of creative nonfiction works that follow authors in their search for more sustainable New Zealand lifestyles include Janet Luke's Green Urban Living: Simple Steps to Growing Food, Keeping Chickens, Worm Farming, Beekeeping and Much More in New Zealand (2011) and Carolann Murray's Mastering the Art of Self-Sufficiency in New Zealand (2010). Focusing on life in the city, Nissen documents her recipes for household cleaning and beauty products, gardening pest and weed sprays, as well as delicious foundational recipes for such everyday staples as butter, home-cured bacon, apple cider, yogurt, cheese and breads, and some more unusual provisions like fresh rose syrup and Turkish gin. Woven throughout is Nissen's funny and revealing tale of life and its trials and triumphs during this extraordinary year. As their titles suggest, Luke and Murray are committed to a more completely self sufficient lifestyle, although they also assert that moving any way along the spectrum is good for the planet as well as the self. While Nissen's ethos is motivated by reducing the family's exposure to chemicals commonly used in foods and other everyday products, Murray seeks to find alternatives to existing household systems 'that won't need subsequent replacement or running costs' (10). All three books are based on personal experience - Nissen in suburban Auckand, Luke in Hawkes Bay and Murray on a 4.2 hectare farm outside Wellington - and entertainingly mix personal experience with researched information that readers can put to good use.

Ex-restaurateur Richard Till writes for several major newspaper lifestyle supplements in New Zealand, appears regularly on radio food programs and 
has written and hosted a number of television cookery programs. In 2007, his television series Kiwi Kitchen won the New Zealand Guild of Food Writers Ocean Spray Electronic Media Award. I include his book of the second series here as a celebration (in the form of a group biography) of what Till calls New Zealand 'home cooks' (2008: 5) and cookery, starting with his own mother and then progressing around the country. For Till, the link between food, family and tradition inspires creativity and can, in turn, lead to enhanced cooking skills:

In the end, it's really about the food our mothers made for us and the recipes and traditions they have handed down. Opening the back door of the family home to be greeted by the delightful smell of a roast in the oven is heart-warming in the extreme. The tantalising aroma of a meal cooking is one of the ways we extend the pleasure of food into the hours before it arrives. ...The key attributes of successful cookery are enthusiasm for the tasks involved, and a sense of love and care for the ingredients - and for those for whom you are cooking (Till 2008: 5).

An interest in popular culture is manifest throughout Till's work - and not just in the menus and the dishes that comprise them. The book is illustrated with lovingly photographed images of his featured cooks and their kitchens, dining rooms, gardens and even a number of vintage caravans. Also featured are these home cooks' everyday (often 'classic') cooking implements and pots and pans, as well as crockery, cutlery and vintage tea towels from Till's collection, exploring the links between objects, meaning and memory. Till profiles fifty of his vintage tea towels in Every Tea Towel Tells a Story: Richard Till's Special Collection (2010), telling the story of his collection in a book that could become a model for similar volumes describing and showcasing such culinary textiles as tablecloths and aprons. Although I agree with Bloom that when food writing is practiced by good writers, 'whether they can cook or not is beside the point' (Bloom 2008: 346), when the two skills come together as in Till's prose, the result is doubly delectable.

Much contemporary culinary writing has a strongly autobiographical tendency, with the food memoir and, even, the food writers' memoir, recognisable (sub)genres (Brien 2011). In terms of life writing about food, personal essays abound in New Zealand serials, but biographies and biographical studies are also a feature of contemporary food writing practice. This is not new with notable studies of winemakers such as Dick Scott's group biographical study Winemakers of New Zealand (1964) and Stake in the Country: Assid Abraham Corban (1977, 2002), the biography of a pioneering wine-maker. More recent biographical studies from New Zealand include Tessa Anderson's Jane Hunter: Growing a Legacy (2008) which I include here as it not only indicates the interest in writing about wine of all kinds in that country but also a blending of autobiographical and biographical reflection. This book follows the life story of an important figure in the New Zealand wine industry, the South Australian born viticulturist, winery-owner and marketer who Anderson credits as having helped to establish the Marlborough region's Sauvignon Blanc as an international brand. As is obvious from the acknowledgements, Hunter as subject contributed significantly to this book, but telling the story as a life narrative in the third person allows Anderson to provide some valuable external commentary on both Hunter's contribution to the industry and her personal life. Anderson was, however, also personally connected to the story she was telling, with a background in wine growing and as well as wine writing, and living in the Marlborough region when she wrote the book. 
Frances Walsh's social history Inside Stories: A History of the New Zealand Housewife 1890-1975 (2011) is included in this selection as it indicates a collection of recent New Zealand books that, while not entirely about culinary matters, include significant information about the subject. It is also fascinatingly focused on magazines, responding to Rosemary Williamson's call for research into Australasian magazines and the way 'genres are crafted, presented and produced for the consumption of defined audiences' (Williamson 2008). This beautifully-illustrated and exquisitely-designed book, which Walsh describes as 'a wayward compendium of housewives' lore and preoccupations' (18), investigates the image and role of the housewife in New Zealand, using a range of women's magazines as her primary source materials. In this, she utilises some 20 New Zealand titles, all now defunct, except for the New Zealand Woman's Weekly. The Auckland-based author draws upon extensive inside knowledge of this industry as she has had long career in journalism, including as a documentary researcher and as a senior writer for Metro magazine, where she won several awards for her work. In terms of writing about food, the book contains a chapter titled 'The Kitchen: Keeping the Tins full and Getting Dinner on the Table' (130-159), which surveys attitudes to domestic cookery, cooking technologies and recipes in New Zealand magazines, as well as a very revealing selection of unique poetry on the subject of nappery, crockery and cookery. Other information on food and matters culinary is, moreover, sprinkled through many of the other chapters, especially those on 'The Husband' (100-129) and 'The Shopping' (200-225) as the gustatory is seen to be central to these parts of domestic life.

\section{Conclusion: Digesting the feast}

Each of these thoroughly researched, beautifully written and splendidly presented books is an absorbing pleasure to read. These volumes are also valuable resources on the subject of New Zealand cuisine and cookery and attitudes towards these key aspects of everyday life, as together, they provide a detailed and entertaining-to-consume narrative of New Zealand food and culinary culture. They also provide a revealing commentary on the extremely high quality food writing being produced and published in New Zealand, food writing that is vivid and engaging, and which makes an important contribution to the literary culture of Australasia.

\section{Works discussed}

Anderson, Tessa 2008 Jane Hunter: Growing a Legacy, Harper Collins New Zealand, Auckland

[ISBN 9781869506483 , Hardback, 320 pp., NZ\$40.00] return to text

Burton, David 2009 New Zealand Food and Cookery, David Bateman, Auckland

[ISBN 9781869537289 , Hardback, 320 pp., NZ\$60.00] return to text

Leach, Helen 2008 The Pavlova Story: A Slice of New Zealand's Culinary

History, Otago University Press, Dunedin

[ISBN 9781877372575, Paperback, 192 pp., NZ\$40.00] return to text

Leach, Helen (ed.) 2010 From Kai to Kiwi Kitchen: New Zealand Culinary

Traditions and Cookbooks, Otago University Press, Dunedin

[ISBN 9781877372759, Paperback, 219 pp., NZ\$45.00] return to text 
Leach, Helen, Mary Browne and Raelene Inglis 2011 The Twelve Cakes of Christmas: An Evolutionary History with Recipes, Otago University Press, Dunedin

[ISBN 9781877578199, Hardback, 192 pp., NZ\$40.00] return to text

Luke, Janet 2011 Green Urban Living: Simple Steps to Growing Food, Keeping Chickens, Worm Farming, Beekeeping and Much More in New Zealand, New Holland, Auckland

[ISBN 9781869663223, Paperback, 176 pp., NZ\$45.00] return to text

Murray, Carolann 2010 Mastering the Art of Self-Sufficiency in New Zealand, New Holland, Auckland

[ISBN 9781869662912, Paperback, 224 pp., NZ\$39.00] return to text

Nissen, Wendy 2010 A Home Companion: My Year of Living Like my Grandmother, Allen \& Unwin, Crows Nest

[ISBN 9781877505058, Paperback, 302 pp., NZ\$26.99] return to text

Rowland, Perrin 2010 Dining Out: A History of the Restaurant in New Zealand, Auckland University Press, Auckland

[ISBN 9781869404642, Hardback, 280 pp., NZ\$59.99] return to text

Stewart, Keith 2010 Chancers and Visionaries: A History of New Zealand Wine, Godwit/Random House New Zealand, Auckland

[ISBN 9781869620709, Paperback, 447 pp., NZ\$49.99] return to text

Till, Richard 2008 Kiwi Kitchen with Richard Till (TVNZ/Googlebox Productions), Renaissance Publishing, Auckland [ISBN 9780958263566, Paperback, 144 pp., NZ\$34.99] return to text

Till, Richard 2010 Every Tea Towel Tells a Story: Richard Till's Special Collection, Renaissance Publishing, Auckland [ISBN 9780986452109, Paperback, 112 pp., NZ\$24.99] return to text

Veart, David 2008, reprinted 2009, First Catch Your Weka: A Story of New Zealand Cooking, Auckland University Press, Auckland [ISBN 97818699404109, Paperback, 330 pp., NZ\$49.99] return to text

Walsh, Frances 2011 Inside Stories: A History of the New Zealand Housewife 1890-1975, Godwit, Random House, Auckland

[ISBN 9781869621650, Paperback, 320 pp., NZ\$49.99] return to text

\section{Works cited}

Bloom, LZ 2008 'Consuming prose: The delectable rhetoric of food writing', College English 70, 4: 346-61 return to text

Brien, DL 2011 'Pathways into an "elaborate ecosystem": Ways of categorising the food memoir', TEXT 15, 2 (October):

http://www.textjournal.com.au/oct11/brien.htm (accessed 11 November 2011) return to text

Bullock, O 2007 'Making canons and finding flowers - A study of selected New Zealand poetry anthologies', MA Thesis, University of Waikato, New Zealand return to text 
Evans, P 2007 The Long Forgetting: Postcolonial Literary Culture in New Zealand, Canterbury University Press: Christchurch return to text

Griffith, P, R Harvey \& K Maslen (eds) 1997 Book and Print in New Zealand: A Guide to Print Culture in Aotearoa, Victoria University Press, Wellington return to text

Griffith, P, P Hughes \& A Loney (eds) 2000 A Book in the Hand: Essays on the History of the Book in New Zealand, Auckland University Press, Auckland return to text

McEldowney, D 2000 'Preface' in P Griffith, P Hughes \& A Loney (eds) A Book in the Hand: Essays on the History of the Book in New Zealand, Auckland University Press, Auckland: vii-xii return to text

NZFHS [The New Zealand Food History Society] 2012 http://web.mac.com/nzfoodhistory/NZ_Food_History/Home.html (accessed 1 March 2012) return to text

NZGFW [The New Zealand Guild of Food Writers] 2012 http://www.foodwriters.org.nz (accessed 1 March 2012) return to text

Pittaway, G 2011 'The spiral of leadership in the teaching of creative writing in New Zealand', in Leadership in Writing and the Creative Arts, TEXT Special Issue Website Series 12 (October): http://www.textjournal.com.au/issue12/Pittaway.pdf (accessed 12 February 2012) return to text

Reid, JC 1946 Creative Writing in New Zealand, Whitcombe and Tombs, Christchurch return to text

Robinson, R \& N Wattie (eds) 1998 'Introduction', in The Oxford Companion to New Zealand Literature, Oxford University Press, Auckland http://www.bookcouncil.org.nz/Writers/Information/Oxford-Companion.htm (accessed 12 February 2012) return to text

Scott, D 1964 Winemakers of New Zealand, Southern Cross Books, Auckland return to text

Scott, D 1977, 2002 A Stake in the Country: Assid Abraham Corban and his Family, 1892-1977 (repub as A Stake in the Country: Assid Abraham Corban and his Family, 1892-2002), Reed, Auckland return to text

Sturm, T (ed) 1998, 1991 The Oxford History of New Zealand Literature in English, Oxford University Press, Auckland return to text

Williamson, R 2008 'The case of the writer, the academic and the magazine', TEXT 12, 1: http://www.textjournal.com.au/apr08/williamson (accessed 10 February 2012) return to text

Donna Lee Brien BEd (Deakin), MA (UTS), PhD (QUT), GradCert HighEd (UNE), is Professor of Creative Industries and Assistant Dean, Research \& Postgraduate, in the School of Creative and Performing Arts at Central Queensland University, Australia. Widely published in the areas of writing praxis and pedagogy and creative nonfiction, her biography John Power 18811943 (Sydney: 1991) is the standard work on this expatriate artist/benefactor. 
Donna is co-author with Tess Brady of The Girl's Guide to Real Estate: How to Enjoy Investing in Property (2002) and The Girl's Guide to Work and Life: How to Create the Life YouWant (2004) (both Allen \& Unwin, Sydney). Founding Editor of dotlit: Online Journal of Creative Writing (2000-2004), Donna is the Special Issues Editor of TEXT: Journal of Writers and Writing Programs, a Founding Editorial Board member of LOCALE: The AustralasianPacific Journal of Regional Food Studies and Past President of the Australasian Association of Writing Programs. Donna has been writing about food writers and their influence in scholarly and popular publications since 2006, and co-edited the 2012 food-themed special issue of the Australasian Journal of Popular Culture with Dr Toni Risson.

TEXT

Vol 16 No 1 April 2012

http://www.textjournal.com.au

Editors: Nigel Krauth \& Enza Gandolfo

Text@griffith.edu.au 